\title{
3 Economic and environmental impacts of power supply configuration change in China
}

\author{
An application of scenario \\ input-output analysis
}

\author{
Jiayang Wang and Kiyoshi Fujikawa
}

\section{Introduction}

China's energy consumption has increased rapidly in the last decade, and it has become the largest energy consumer and $\mathrm{CO}_{2}$ emitter in the world. Saving energy and reducing emissions are becoming urgent issues in China. China has declared that $\mathrm{CO}_{2}$ emissions per GDP will be reduced by $60 \%-65 \%$ (compared with that in 2005) and the total carbon emissions will peak by 2030 as stated in the Nationally Determined Contributions in the Paris Agreement in 2015 (National Development and Reform Committee of China, 2015). Moreover, at the United Nations' 2020 General Assembly, China made an ambitious pledge that China will be a carbon-neutral country before $2060 .{ }^{1}$ China's economy is highly dependent on fossil energy, especially on coal. Coal-fired power generation provides approximately $70 \%$ of China's total power generation, and the power generation sector accounts for nearly $50 \%$ of China's total $\mathrm{CO}_{2}$ emissions (NBSC, 2020; World Input-Output Database, 2013). China needs to reform its energy structure and reduce coal consumption to achieve these targets.

Although renewable power generation is now rapidly spreading throughout China, there are some issues which deserve discussions. For example, it is not clear how much $\mathrm{CO}_{2}$ emissions can be reduced when coal-fired power generation is replaced by renewable energies. Moreover, it is not clear, given the replacement of coal-fired power generation with renewable energies, whether energy shifts will have a negative impact on the economy/employment or not, and if it has negative effects on the economy/employment, how large they will be.

Against this backdrop, this chapter applies scenario input-output analysis to estimate the environmental, economic, and social effects by shifting power sources from coal to renewable energies.

\section{Model}

\subsection{Scenario input-output analysis}

Input-output analysis is a convenient economic tool to determine the overall effect of demand shift or structural change on production, energy 
consumption, or $\mathrm{CO}_{2}$ emissions. It is important to note that input-output analysis assumes that one kind of commodity is produced by one kind of activity. However, electricity is produced by such plural activities as thermal power, hydropower, nuclear power, wind power, and solar power. Changing the activity share in the power generation structure will produce different economic, environmental, and social effects even if the final energy demand remains the same.

Several methods have been developed to tackle this objective. Yoshioka and Suga (1997) proposed a methodology that rearranged a rectangular input-output table where one product is produced by plural activities into one square so that the Leontief inverse matrix may be defined. Duchin and Levine $(2011,2012)$ developed a model of Rectangular Choice of Technology (RCOT) with factor constraints that apply linear programming to input-output analysis. The RCOT model allows several input structures in a sector to analyze the economic and environmental effects of technology selection. Fujikawa (2011) applied the RCOT method of Yoshioka and Suga (1997) to analyze thermal and nuclear power substitutability and named this method "scenario input-output analysis." Wang (2016) applied the scenario input-output analysis to estimate economic and environmental effects when the power source shifts from thermal power to renewableenergy power. This analysis used a newly developed input-output table by the Institute for Economic Analysis of Next-Generation Science and Technology, Waseda University, Japan. This chapter will also apply the scenario input-output analysis to estimate how economic, environmental, and social effects differ by changing the power source in China following these previous studies.

The standard input-output table has the comparable industry and commodity names in its rows and columns, respectively. In other words, traditional input-output analysis is based on the standard input-output tables that assume that one commodity is produced by one industry and one industry produces one commodity. Because the input (or technical) structure of each industry is expressed by the corresponding column, one industry name is assumed to be synonymous with "activity." This assumption, however, does not necessarily hold true for all industries in the real economy. The power industry is one of the typical examples where electricity (a commodity in the power industry) is produced by various kinds of activities such as thermal power, window power, solar power, hydropower, and nuclear power. On the other hand, there is only one electricity row on the input side because all activities produce the same good: electricity. However, there are multiple activities (columns) in the electricity industry. The scenario input-output analysis is a method used to combine plural activities into one by giving exogenously the share of the output of each activity.

Figure 3.1 illustrates an input-output table where electric power is generated by five types of energy such as nuclear power, thermal power, hydropower, solar power, and wind power. 


\begin{tabular}{|c|c|c|c|c|c|c|c|c|c|}
\hline & $\begin{array}{c}\text { Intermediate } \\
\text { Input }\end{array}$ & \multicolumn{5}{|c|}{ Power Generation } & \multirow{2}{*}{$\begin{array}{c}\text { Final } \\
\text { Demand }\end{array}$} & \multirow{2}{*}{$\begin{array}{l}\text { Domestic } \\
\text { Product }\end{array}$} \\
\hline & & $\begin{array}{c}\text { Input } \\
j=1, \cdots, n\end{array}$ & $\begin{array}{c}\text { Nuclear } \\
\text { Power }\end{array}$ & $\begin{array}{c}\text { Thermal } \\
\text { Power } \\
\end{array}$ & Hydropower & $\begin{array}{l}\text { Solar } \\
\text { Power } \\
\end{array}$ & $\begin{array}{l}\text { Wind } \\
\text { Power }\end{array}$ & & \\
\hline 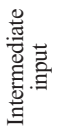 & $\begin{array}{l}= \\
\vdots \\
\approx \\
\approx\end{array}$ & $\mathbf{X}^{11}$ & $\mathbf{x}_{1}^{12}$ & $\mathbf{x}_{2}^{12}$ & $\mathbf{x}_{3}^{12}$ & $\mathbf{x}_{4}^{12}$ & $\mathbf{x}_{5}^{12}$ & $\mathbf{f}^{1}$ & $\mathbf{x}^{1}$ \\
\hline \multicolumn{2}{|c|}{$\begin{array}{c}\text { Power } \\
\text { Generation }\end{array}$} & $\mathbf{x}^{21}$ & $x_{1}^{22}$ & $x_{2}^{22}$ & $x_{3}^{22}$ & $x_{4}^{22}$ & $x_{5}^{22}$ & $f^{2}$ & $x^{2}$ \\
\hline \multicolumn{2}{|c|}{$\begin{array}{l}\text { Value } \\
\text { Added } \\
\end{array}$} & $\mathbf{v}^{1}$ & $v_{1}^{2}$ & $v_{2}^{2}$ & $v_{3}^{2}$ & $v_{4}^{2}$ & $v_{5}^{2}$ & & \\
\hline \multicolumn{2}{|c|}{$\begin{array}{c}\begin{array}{c}\text { Domestic } \\
\text { Product }\end{array} \\
\end{array}$} & $\mathbf{x}^{1^{\prime}}$ & $z_{1}$ & $z_{2}$ & $z_{3}$ & $z_{4}$ & $z_{5}$ & & \\
\hline
\end{tabular}

Figure 3.1 Input-output table with multiple activities in power generation. Source: Compiled by the authors.

The power generation sector is assumed to be composed of five activities: nuclear power, thermal power, hydropower, solar power, and wind power in this chapter. Changing the shares of the activity mix in the electricity industry will bring different economic and environmental effects even if the level of the final demand is unchanged.

\subsection{Production function}

In the model equation, the power sector is expressed by a superscript number 2, and the other sectors are indicated with a superscript number 1 . The other sectors are collectively referred to as the "normal sector." The power sector is subdivided into five activities. The activity subdivision of the power sector is based on the studies by Fujikawa (2011) and Wang (2016).

The production function of the normal sector is expressed in equation 3-1:

$$
x_{j}^{1}=\min \left[x_{i j}^{11} / a_{i j}^{11}, x_{j}^{21} / a_{j}^{21}\right] \quad(i, j=1, \cdots, n),
$$

where

$x_{j}^{1}$ : Output of the normal sector

$x_{i j}^{11}$ : Input from the $i^{\text {th }}$ industry (normal sector) to the $j^{\text {th }}$ industry (normal sector)

$x_{j}^{21}$ : Input from the power sector to the $j^{\text {th }}$ industry (normal sector)

$a_{i j}^{11}$ : Input coefficient from the $i^{\text {th }}$ industry (normal sector) to $j^{\text {th }}$ industry (normal sector)

$a_{j}^{21}$ : Input coefficient from the power sector to the $j^{\text {th }}$ industry (normal sector). 
The production function of the power sector is expressed in equation 3-2:

$$
z_{k}=\min \left[x_{i k}^{12} / a_{i k}^{12}, x_{k}^{22} / a_{k}^{22}\right] \quad(i, j=1, \cdots, n, k=1, \cdots, 5),
$$

where

$z_{k}$ : Output of each activity in the power sector

$x_{i k}^{12}$ : Input from the $i^{\text {th }}$ industry (normal sector) to the $k^{\text {th }}$ activity (power sector)

$x_{k}^{22}:$ Input from the power sector to the $k^{\text {th }}$ activity (power sector)

$a_{i k}^{12}$ : Input coefficient from the $i^{\text {th }}$ industry (normal sector) to the $k^{\text {th }}$ activity (power sector)

$a_{k}^{22}$ : Input coefficient from the power sector to the $k^{\text {th }}$ activity (power sector).

The demand-supply equilibrium for the normal and power sectors can be expressed in simultaneous equations 3-3 and 3-4:

$$
\begin{aligned}
& \mathbf{A}^{11} \mathbf{x}^{1}+\mathbf{A}^{12} \mathbf{z}+\mathbf{f}^{1}=\mathbf{x}^{1}, \\
& \mathbf{a}^{21} \mathbf{x}^{1}+\mathbf{a}^{22} \mathbf{z}+f^{2}=x^{2},
\end{aligned}
$$

where

$\mathbf{A}^{11}$ : Input coefficient matrix from the normal sector to normal sector, $\mathbf{A}^{11}=\left[a_{i j}^{11}\right](n \times n)$

$\mathbf{A}^{12}$ : Input coefficient matrix from the normal sector to power sector, $\mathbf{A}^{12}=\left[a_{i k}^{12}\right](n \times 5)$

$\mathbf{a}^{21}$ : Input coefficient vector from the power sector to normal sector, $\mathbf{a}^{21}=\left[a_{j}^{21}\right](1 \times n)$

$\mathbf{a}^{22}$ : Input coefficient vector from the power sector to power sector, $\mathbf{a}^{22}=\left[a_{k}^{22}\right](1 \times 5)$

$\mathbf{f}^{1}$ : Final demand $(n \times 1)$ vector for the normal sector

$f^{2}$ : Final demand for the power sector, which is a scalar

$\mathbf{x}^{1}$ : Output $(n \times 1)$ vector for the normal sector

$x^{2}$ : Output of the power sector, which is a scalar

$\mathbf{z}$ : Output $(5 \times 1)$ vector of each activity in the power sector.

The final demands $\mathbf{f}^{1}$ and $f^{2}$ are exogenous variables that are given from outside the equation system. The number of unknown endogenous variables in the above simultaneous equations is $n+6 ; n$ in $\mathbf{x}^{1}, 1$ in $x^{2}$, and 5 in $z$, and the number of equations is no more than $n+1$. Since the number of equations is less than the unknown endogenous variables, we cannot solve the above simultaneous equation as it is. Therefore, we need to add certain assumptions or "scenarios" to solve the equations. 


\subsection{Assumptions}

We set two assumptions to solve the equations.

Assumption 1: All of the electricity produced through the five different energy sources is supplied and consumed.

$$
z_{1}+z_{2}+z_{3}+z_{4}+z_{5}=x^{2},
$$

where $z_{1}, z_{2}, z_{3}, z_{4}$, and $z_{5}$ stand for the nuclear power output, thermal power output, hydropower output, solar power output, and wind power output, respectively.

Assumption 2: The power supply configuration is given by exogenous parameters.

$$
\left\{\begin{array}{l}
z_{1}=\alpha_{1} x^{2} \\
z_{2}=\alpha_{2} x^{2} \\
z_{3}=\alpha_{3} x^{2} \\
z_{4}=\alpha_{4} x^{2} \\
z_{5}=\left(1-\alpha_{1}-\alpha_{2}-\alpha_{3}-\alpha_{4}\right) x^{2}
\end{array}\right.
$$

where $\alpha_{1}, \alpha_{2}, \alpha_{3}, \alpha_{4}$ and $\alpha_{5}$ stand for the shares of the nuclear power output, thermal power output, hydropower output, solar power output, and wind power output, respectively.

The above two assumptions are summarized in the following matrix equation, which we call the "scenario equation."

$$
\begin{aligned}
& {\left[\begin{array}{c}
z_{1} \\
z_{2} \\
z_{3} \\
z_{4} \\
z_{5}
\end{array}\right]=\left[\begin{array}{c}
\alpha_{1} \\
\alpha_{2} \\
\alpha_{3} \\
\alpha_{4} \\
1-\alpha_{1}-\alpha_{2}-\alpha_{3}-\alpha_{4}
\end{array}\right] x^{2},} \\
& \mathbf{z}-\mathbf{c} x^{2}=0 \\
& \text { where } z=\left[\begin{array}{c}
z_{1} \\
z_{2} \\
z_{3} \\
z_{4} \\
z_{5}
\end{array}\right] \mathbf{c}=\left[\begin{array}{c}
\alpha_{1} \\
\alpha_{2} \\
\alpha_{3} \\
\alpha_{4} \\
1-\alpha_{1}-\alpha_{2}-\alpha_{3}-\alpha_{4}
\end{array}\right] .
\end{aligned}
$$

As the number of equations increases by 5 because of these assumptions, the total number of unknown variables matches the total number of equations. We can then solve simultaneous equations 3-3 and 3-4. 


\subsection{Estimating the economic, environmental, and social impacts}

Equation 3-7 can be modified into equation 3-7'.

$$
\mathbf{z}=\mathbf{c} x^{2} \text {. }
$$

Substitution of equation 3-7' into equations 3-3 and 3-4 gives equations 3-8 and 3-9.

$$
\begin{gathered}
\mathbf{A}^{11} \mathbf{x}^{1}+\mathbf{A}^{12} \mathbf{c} x^{2}+\mathbf{f}^{1}=\mathbf{x}^{1}, \\
\mathbf{a}^{21} \mathbf{x}^{1}+\mathbf{a}^{22} \mathbf{c} x^{2}+f^{2}=x^{2} .
\end{gathered}
$$

Then, we get equation 3-10.

$$
\left[\begin{array}{ll}
\mathbf{A}^{11} & \mathbf{A}^{12} \mathbf{c} \\
\mathbf{a}^{21} & \mathbf{a}^{22} \mathbf{c}
\end{array}\right]\left[\begin{array}{l}
\mathbf{x}^{1} \\
x^{2}
\end{array}\right]+\left[\begin{array}{l}
\mathbf{f}^{1} \\
f^{2}
\end{array}\right]=\left[\begin{array}{l}
\mathbf{x}^{1} \\
x^{2}
\end{array}\right] .
$$

Finally, we obtain equilibrium output equation 3-11. It is important that the input coefficient vector of the power sector is defined as a weighted average of those of five activities in the power sector.

$$
\left[\begin{array}{l}
\mathbf{x}^{1} \\
x^{2}
\end{array}\right]=\left[\mathbf{I}-\left[\begin{array}{cc}
\mathbf{A}^{11} & \mathbf{A}^{12} \mathbf{c} \\
\mathbf{a}^{21} & \mathbf{a}^{22} \mathbf{c}
\end{array}\right]\right]^{-1}\left[\begin{array}{c}
\mathbf{f}^{1} \\
f^{2}
\end{array}\right] .
$$

We can calculate the outputs of $\mathbf{x}^{1}$ and $x^{2}$ when the final demands $\mathbf{f}^{1}$ and $f^{2}$ are given. The Leontief inverse matrix depends on the scenario or the share of the activities in the power sector.

The total $\mathrm{CO}_{2}$ emissions (emi) can be calculated using the $\mathrm{CO}_{2}$ emission coefficients $\mathbf{e}_{\boldsymbol{x}}$ and $\mathbf{e}_{z}$ for the normal and power sectors, respectively, as shown in equation 3-12.

$$
\mathbf{e m i}=\left[\begin{array}{ll}
\mathbf{e}_{x} & \mathbf{e}_{z}
\end{array}\right]\left[\begin{array}{c}
\mathbf{x}^{1} \\
\mathbf{z}
\end{array}\right] .
$$

The total required labor force (eng) can be estimated using labor coefficients $\mathbf{l}_{\boldsymbol{x}}$ and $\mathbf{l}_{\boldsymbol{z}}$, which are defined as labor input per unit output of the corresponding sector, as shown in equation 3-13.

$$
\text { eng }=\left[\begin{array}{ll}
\mathbf{l}_{x} & \mathbf{l}_{z}
\end{array}\right]\left[\begin{array}{c}
\mathbf{x}^{1} \\
\mathbf{z}
\end{array}\right] .
$$

\section{Data}

\subsection{Input-output tables}

We used the "2012 Input-Output Table of China" issued by the National Bureau of Statistics of China (NBSC) for our data. However, the power sector in the input-output table of China is not divided by power generation activity. We estimated an input-output table where the power generation 
sector is divided into nuclear, thermal, hydro, and renewable energy based on "The Input-Output Table for Analysis of the Next-Generation Energy System for 2005" (Institute for Economic Analysis of Next-generation Science and Technology). ${ }^{2}$ We borrowed the input coefficients from the Waseda University table, where we assumed that the input coefficients of the power generation sector are similar between Japan and China.

\subsection{Energy consumption and $\mathrm{CO}_{2}$ emissions ${ }^{3}$}

We used the following three-step method when we estimated $\mathrm{CO}_{2}$ emission coefficient by industry.

i Step 1: Nominal value of fossil energy input by industry

We calculated the nominal consumption value of three fossil energies such as coal, oil, and natural gas using the "2012 Input-Output Table of China" (NBSC, 2015).

ii Step 2: Calorie-based fossil energy input by industry

We got calorie-based total fossil energy consumption from the "China Energy Statistical Yearbook 2013" (NBSC, 2013). We calculated the calorie-based fossil energy input by industry by multiplying the calorie-based total fossil energy consumption and nominal consumption share of each industry, which is obtained in Step 1.

iii Step 3: $\mathrm{CO}_{2}$ emissions by industry

We used $\mathrm{CO}_{2}$ emission coefficients in the "2006 IPCC Guidelines for National Greenhouse Gas Inventories" issued by the Intergovernmental Panel on Climate Change (IPCC; Table 3.1). ${ }^{4}$ We calculated $\mathrm{CO}_{2}$ emissions by industry as a product of $\mathrm{CO}_{2}$ emission coefficients and calorie-based fossil energy consumption by industry, which was obtained in Step 2.

\subsection{Required employment}

Labor data are based on "Socio Economic Accounts 2016" issued by the World Input-Output Database (WIOD; Timmer et al., 2015). The WIOD labor data are often used in calculating labor coefficients by industry but the sector classification in manufacturing is too approximate to apply to

Table $3.1 \mathrm{CO}_{2}$ emission coefficients by fuel type

\begin{tabular}{lcc}
\hline Fuel type & Carbon content $(\mathrm{kg}-\mathrm{C} / \mathrm{TJ})$ & $\begin{array}{l}\text { Effective } \mathrm{CO}_{2} \text { emissions } \\
\left(\mathrm{kg}-\mathrm{CO}_{2} / \mathrm{TJ}\right)\end{array}$ \\
\hline Coal & 25.8 & 94.6 \\
Oil & 20.0 & 73.3 \\
Natural gas & 15.3 & 56.1 \\
\hline
\end{tabular}

Source: The authors' compilation based on IPCC (2006). 
our analysis. We therefore used the share of labor data issued in the China Economic Census Yearbook 2013 (NBSC, 2014), where we retrieved more detailed statistics. Moreover, we used the labor coefficients for power generation activities in the "Renewable Energy-Focused Input-Output Table" (Hienuki et al., 2015).

\section{Results}

\subsection{Scenarios for analysis}

China has set a goal of achieving carbon neutrality by 2060. China's nonfossil fuel power generation will need to increase more than $90 \%$ by 2050 to achieve that goal $(\mathrm{He}, 2020)$. Although significant growth in renewableenergy generation is needed, this study focuses on wind and solar power generation. We excluded hydroelectric power generation as well as nuclear power because both take a long time from planning to operation and their shares are fixed in the current situation. The power supply share in China as of 2012 is as follows: $79 \%$ thermal power, $2 \%$ nuclear power, $17 \%$ hydropower, and $2 \%$ new energy of wind and solar power. Therefore, we fixed approximately $20 \%$ for nuclear and hydropower, and we distributed the remaining $80 \%$ to thermal, wind, and solar power. Then, we implemented the following two simulations: (1) wind power generation replaces thermal power generation, and (2) solar power generation replaces thermal power generation. Finally, we calculated the production, employment, and $\mathrm{CO}_{2}$ emission effects in each power supply configuration scenario.

\subsection{Impacts on economy, $\mathrm{CO}_{2}$ emissions, and employment by increase of renewable power generation}

Tables 3.2 and 3.3 show the estimated impacts when renewable power generation replaces thermal power generation by every $20 \%$. Because the ratio of the hydropower and nuclear power is assumed to be fixed as $20 \%$, the replacement ratio for renewable power can be up to $80 \%$. The first row shows the share of renewable power. The second, the third, and the fourth row show the changes in total production, in $\mathrm{CO}_{2}$ emissions, and the employees,

Table 3.2 Change of output, $\mathrm{CO}_{2}$, and employment by the energy switch to wind power

\begin{tabular}{llccc}
\hline Wind power share & $20(\%)$ & $40(\%)$ & $60(\%)$ & $80(\%)$ \\
\hline Change of total output & -0.4 & -0.8 & -1.2 & -1.5 \\
Change in $\mathrm{CO}_{2}$ emissions & -9.9 & -19.5 & -28.0 & -35.4 \\
Change of employment & -0.1 & -0.2 & -0.3 & -0.3 \\
\hline
\end{tabular}

Source: The authors' compilation. 
Table 3.3 Change of output, $\mathrm{CO}_{2}$, and employment by the energy switch to solar power

\begin{tabular}{lrrrr}
\hline Solar power share & $20(\%)$ & $40(\%)$ & $60(\%)$ & $80(\%)$ \\
\hline Change of total output & 0.6 & 1.2 & 1.6 & 2.0 \\
Change in $\mathrm{CO}_{2}$ emissions & -13.4 & -17.7 & -25.3 & -32.0 \\
Change of employment & 0.6 & 1.0 & 1.4 & 1.8 \\
\hline
\end{tabular}

Source: The authors' compilation.

respectively. If the value of the cell is positive, the estimated value is higher than the current status, and vice versa.

Table 3.2 shows the estimated changes when wind power generation replaces thermal power generation by every $20 \% . \mathrm{CO}_{2}$ emissions will decrease significantly as the replacement by wind power increases. If the replacement rate is $80 \%, \mathrm{CO}_{2}$ emissions will decrease by $35.4 \%$. Total output and number of employees will also decrease to some extent when the replacement rate increases as the ratio of wind power increases. If the replacement rate becomes $80 \%$, the total output and the number of employees will decrease by $1.48 \%$ and $0.34 \%$, respectively. In short, the replacement of thermal power generation with wind power generation can greatly reduce $\mathrm{CO}_{2}$ emission but reduce the total output and number of employees only marginally.

Table 3.3 shows the estimated changes when solar power generation replaces thermal power generation by every $20 \%$. The higher replacement by solar power will reduce $\mathrm{CO}_{2}$ emissions further as we have observed in the case of wind power generation. If the replacement rate is $80 \%, \mathrm{CO}_{2}$ will be decreased by $32 \%$, which is slightly lower than the case of wind power generation. On the other hand, unlike the case of wind power generation, the total output and the number of employees increase when the replacement rate increases. If the replacement rate is $80 \%$, the total output will increase by $2 \%$, and the number of employees will increase by $1.8 \%$. In other words, the replacement of thermal power generation with solar power generation can contribute to a reduction of $\mathrm{CO}_{2}$ emissions and an increase in total output and the number of employees.

\subsection{Impacts on the thermal power and related industries by increase of renewable power generation}

He et al. (2019) point out that an increased share of renewable energy inhibits such thermal power related industries as mining and coal products though it can promote renewable-energy industry development. Our analysis also shows the same result.

Table 3.4 shows that an energy shift to wind power will significantly reduce the output of thermal power and the related industries. In particular, coal/petroleum/gas, coke/refined petroleum, waste treatment, gas supply, nonmetallic mineral, and transportation will be greatly affected. Also, the 
Table 3.4 Output and employment change of thermal power and related industries by the energy switch to wind power

\begin{tabular}{llcccc}
\hline & Wind power share & $20 \%$ & $40 \%$ & $60 \%$ & $80 \%$ \\
\hline Output & $\begin{array}{l}\text { Coal, petroleum, and } \\
\text { Change (\%) }\end{array}$ & $-6.67 \%$ & $-13.16 \%$ & $-18.82 \%$ & $-23.80 \%$ \\
& natural gas & & & & \\
& Coke, refined petroleum & $-2.70 \%$ & $-5.33 \%$ & $-7.62 \%$ & $-9.64 \%$ \\
& Waste treatment & $-1.80 \%$ & $-3.56 \%$ & $-5.08 \%$ & $-6.43 \%$ \\
& Gas supply & $-1.41 \%$ & $-2.79 \%$ & $-3.99 \%$ & $-5.05 \%$ \\
& Nonmetallic mineral & $-1.28 \%$ & $-2.51 \%$ & $-3.59 \%$ & $-4.54 \%$ \\
Employment & Transport & $-0.48 \%$ & $-0.95 \%$ & $-1.36 \%$ & $-1.72 \%$ \\
Change & Coal, petroleum, and & -899 & $-1,776$ & -2.540 & $-3,211$ \\
(1000 & natural gas & -461 & -910 & $-1,301$ & $-1,645$ \\
person) & Transport & -113 & -223 & -319 & -403 \\
& Coke, refined petroleum & -28 & -55 & -80 & -101 \\
& Nonmetallic mineral & -21 & -42 & -60 & -76 \\
& Gas supply & -4 & -9 & -13 & -17 \\
\hline
\end{tabular}

Source: The authors' compilation.

Table 3.5 Output and employment change in thermal power and related industries by the energy switch to solar power

\begin{tabular}{|c|c|c|c|c|c|}
\hline & Solar power share & $20 \%$ & $40 \%$ & $60 \%$ & $80 \%$ \\
\hline \multirow[t]{6}{*}{$\begin{array}{l}\text { Output } \\
\text { change }(\%)\end{array}$} & $\begin{array}{l}\text { Coal, petroleum, } \\
\text { and natural gas }\end{array}$ & $-5.67 \%$ & $-11.31 \%$ & $-16.22 \%$ & $-20.54 \%$ \\
\hline & $\begin{array}{l}\text { Coke, refined } \\
\text { petroleum }\end{array}$ & $-1.62 \%$ & $-3.31 \%$ & $-4.78 \%$ & $-6.08 \%$ \\
\hline & Gas supply & $-1.16 \%$ & $-2.33 \%$ & $-3.34 \%$ & $-4.23 \%$ \\
\hline & Waste treatment & $-0.24 \%$ & $-0.63 \%$ & $-0.98 \%$ & $-1.29 \%$ \\
\hline & Nonmetallic mineral & $0.19 \%$ & $0.30 \%$ & $0.40 \%$ & $0.48 \%$ \\
\hline & Transport & $1.36 \%$ & $2.41 \%$ & $3.31 \%$ & $4.11 \%$ \\
\hline \multirow{7}{*}{$\begin{array}{l}\text { Employment } \\
\text { change } \\
(1000 \\
\text { person) }\end{array}$} & Thermal power & -899 & -1776 & -2540 & -3211 \\
\hline & $\begin{array}{l}\text { Coal, petroleum, } \\
\text { and natural gas }\end{array}$ & -392 & -782 & -1122 & -1420 \\
\hline & $\begin{array}{l}\text { Coke, refined } \\
\text { petroleum }\end{array}$ & -17 & -35 & -50 & -64 \\
\hline & Gas supply & -4 & -8 & -12 & -15 \\
\hline & Waste treatment & -1 & -2 & -3 & -4 \\
\hline & Nonmetallic mineral & 23 & 41 & 56 & 70 \\
\hline & Transport & 44 & 70 & 93 & 113 \\
\hline
\end{tabular}

Source: The authors' compilation.

shift to wind power will significantly reduce the labor demand in the thermal power and related industries. If the ratio of wind power becomes $80 \%$, the employment in thermal power generation will decrease by more than 3 million and those in the above-mentioned thermal power related industries will decrease by more than 2 million.

Table 3.5 shows the results of the solar power replacement. Solar power replacement will have positive effect on the economy while it reduces the 
output and labor demand of thermal power and the related industries such as coal/petroleum/gas, coke/refined petroleum, waste treatment, and gas supply.

However, the impact of the replacement of thermal power generation by solar power generation is different from those of replacement by wind power generation, and the negative impacts on thermal power generation and related industries are not that large. Actually, the production will increase in sectors such as non-metal mineral products and transportation.

\section{Discussion}

The replacement of thermal power generation with renewable energy will greatly contribute to the reduction of $\mathrm{CO}_{2}$ emissions in China, but the economic and social effects are not the same between wind power and solar power. In the case of $80 \%$ replacement by wind power, China's total output and employment will decrease by $1.48 \%$ and $0.34 \%$, respectively. However, in the case of $80 \%$ replacement by solar power, China's total output and employment will increase by $2.0 \%$ and $1.8 \%$, respectively.

Let us discuss the reasons why wind power and solar power generation have different economic effects. California's Clean Energy Future (CCEF) (2012) shows that the job creation effect of renewable energy is larger than that of thermal power generation, except wind power generation. IRENA (2020) suggests that the required labor force for wind power generation is less than the required labor force for solar power generation, and the relative share for the 'operation \& maintenance' that is classified as intermediate inputs of wind power generation is smaller than that of solar power generation as shown in Table 3.6. Similar results have been reported by Wei et al. (2010), Shirley and Kammen (2012), Moriizumi et al. (2017), and He et al. (2019).

The reason why the overall effect of replacement by solar power is positive is that the total of input coefficient for the solar power is higher than that for the wind power. That means, solar power generation requires more inputs from such industries as building repairs, mechanical repairs, transport, and nonmetallic products than wind power.

As a matter of fact, in comparing wind and solar power plants with the same capacity in China, the annual power generation of a wind power plant

Table 3.6 Share of employment by stage of renewable energy value chains

\begin{tabular}{lccccccc}
\hline & Planning & Manufacturing & Transport & Installation & $\begin{array}{c}\text { Operation \& } \\
\text { maintenance }\end{array}$ & $\begin{array}{l}\text { Decommis- } \\
\text { sioning }\end{array}$ & $\begin{array}{l}\text { Labor } \\
\text { requirement* }\end{array}$ \\
\hline Solar power & $1 \%$ & $22 \%$ & $2 \%$ & $17 \%$ & $56 \%$ & $2 \%$ & 229,055 \\
Wind power** & $2 \%$ & $17 \%$ & $1 \%$ & $30 \%$ & $43 \%$ & $7 \%$ & 144,420 \\
\hline
\end{tabular}

\footnotetext{
* Person days for $50 \mathrm{MW}$ plant.

** Onshore wind power.

Source: The authors' compilation based on International Renewable Energy Agency (IRENA) (2020), p. 63.
} 
Table 3.7 Installed capacity and power generation in renewable energy in China in 2019

\begin{tabular}{lccc}
\hline & $\begin{array}{l}\text { Installed capacity } \\
(\mathrm{GW})\end{array}$ & $\begin{array}{l}\text { Power generation } \\
(\mathrm{TWh})\end{array}$ & $\begin{array}{l}\text { Annual power } \\
\text { generation* }(\mathrm{kWh})\end{array}$ \\
\hline Solar power & 175 & 178 & 1,200 \\
Wind power & 184 & 366 & 2,000 \\
\hline
\end{tabular}

* Power generation with $1 \mathrm{~kW}$ capacity.

Source: CEC (2021).

is much higher than that of a solar power plant. Table 3.7 shows the installed capacity and annual power generation of renewable energies in China. The annual power generation of a wind power plant with $1 \mathrm{~kW}$ capacity is around 2,000 kWh, whereas that of a solar power plant is no more than $1,200 \mathrm{kWh}(\mathrm{CEC}, 2021)$. In other words, solar power plants require at least 1.5 times capacity compared with wind power plants to generate the same amount of power.

The negative impacts on thermal power and related industries are inevitable when thermal power generation is replaced by renewal energies although there is a difference in the magnitude of impact between wind power and solar power. The labor demand decrease in coal mining is expected to be particularly large. Relocation of workers in the coal mining industry is not easy since the majority of workers in the coal industry are unskilled. Now China introduces wind power generation on a large scale to replace the thermal power generation. The Chinese government has to figure out how to rehire retirees from the coal mining industry.

\section{Conclusions}

This chapter focuses on China's power industry from the perspective of power supply configuration. The power industry is composed of multiple power generation activities such as nuclear power, hydropower, thermal power, wind power, and solar power. It was therefore difficult to handle the power industry through the traditional framework of input-output analysis. However, scenario input-output analysis makes it possible to analyze the difference in the economic, environmental, and social effects caused by the different power supply configurations. Scenario input-output analysis gives shares of multiple power generation activities in the power sector as parameters that integrate multiple activities into one column in a square input-output table.

We find that the replacement of thermal power generation with renewable energy might greatly contribute to the reduction of $\mathrm{CO}_{2}$ emissions in China. If all thermal power generation is replaced by renewable energy, China's $\mathrm{CO}_{2}$ emissions can be reduced by more than $30 \%$. However, the impacts 
on the economy are different between replacement by wind power and replacement by solar power. Replacement by the wind power has negative effects on the economy while replacement by the solar power might have positive effects on the economy. The reason for this is that equipment for the solar power generation is composed of more parts and requires more time and more labor force for maintenance and repair compared with the wind power. Although wind power replacement has negative effects on the economy, its relative scale is extremely small compared with its $\mathrm{CO}_{2}$ reduction effect. The results show the possibility of simultaneous realization of economic growth and reduction of $\mathrm{CO}_{2}$ emissions when the thermal power generation is replaced by renewable-energy power generation.

Moreover, the negative impacts on thermal power and related industries are inevitable when thermal power generation is replaced by renewable power. The negative impacts are especially serious in coal mining and coal products. When China promotes renewable power generation, adjustment policies will be required to mitigate the negative impacts of reduced production and employment in these industries.

\section{Acknowledgments}

This work was supported by Japan Society for the Promotion of Science, Grants-in-Aid for Scientific Research, under Grant Numbers JP18H03426, JP19K12459, JP20K12291, and Nagoya University.

\section{Notes}

1 See UN News dated on 22 September 2020, https://news.un.org/en/story/ 2020/09/1073052/ [accessed 31 January 2021].

2 See author and title of the website, http://www.f.waseda.jp/washizu/table.html (in Japanese) / [accessed 31 January 2021].

3 Energy consumption or $\mathrm{CO}_{2}$ emissions in the construction stage of power plants are outside of the scope of this study since this study focuses on the operation stage of power generation.

4 As to the details, see Volume 2 Energy P23-24. Table 1.4, https://www.ipccnggip.iges.or.jp/public/2006gl/vol2.html/ [accessed 31 January 2021].

\section{References}

California's Clean Energy Future (CCEF) 2012. Preliminary estimates of job creation, http://www.bioin.or.kr/fileDown.do?seq=16187/ [accessed 31 January 2021].

Duchin, F., and Levine, S. H. 2011. Sectors may use multiple technologies simultaneously: The rectangular choice-of-technology model with binding factor constraints, Economic Systems Research, 23(3), 281-302. https://doi.org/10.1080/0953 5314.2011.571238

Duchin, F., and Levine, S. H. 2012. The rectangular sector-by-technology model: not every economy produces every product and some products may rely on 
several technologies simultaneously, Journal of Economic Structures. 1(1), 1-11, https://doi.org/10.1186/2193-2409-1-3

Fujikawa, K. 2011. Input output model to evaluate environmental policies, in Ban K. (ed.), Model development for comprehensive analysis on Japanese environmental policies and economy (Final report of Policy Research of Environmental Economics, 2009-2011), 225-267, Ministry of the Environment, Japan, http://www.env. go.jp/policy/keizai_portal/F_research/f-01-03.pdf/ (in Japanese)

He, J. 2020. China's long-term low-carbon development strategy and pathway, the press conference by the Institute of Climate Change and Sustainable Development (ICCSD), https://mp.weixin.qq.com/s/S_8ajdq963YL7X3sRJSWGg/ [accessed 31 January 2021].

He, L., Yang, X., Zhong, Z., and Zhu, J. 2019. On employment effect of renewable energy investment in China: From the overall and industrial perspective, Journal of Central South University (Social Science), 25(3), 84-95, https://doi.org/10.11817/j. issn.1672-3104.2019.03.010. http://www.zndxsk.com.cn/upfile/soft/2019/03_skb/10p84-19sk03.pdf

Hienuki, S., Kudoh, Y., and Hondo, H., 2015. Life cycle employment effect of geothermal power generation using an extended input-output model: The case of Japan, Journal of Cleaner Production, 93, 203-212. https://doi.org/10.1016/j. jclepro.2015.01.008

Intergovernmental Panel on Climate Change (IPCC), 2006. 2006 IPCC guidelines for national greenhouse gas inventories, https://www.ipcc.ch/report/2006-ipccguidelines-for-national-greenhouse-gas-inventories/ [accessed 31 January 2021].

International Renewable Energy Agency (IRENA) (2020). Post-COVID recovery: An agenda for resilience, development and equality, https://www.irena.org/-/media/Files/ IRENA/Agency/Publication/2020/Jun/IRENA_Post-COVID_Recovery_2020.pdf [accessed 31 January 2021].

Moriizumi, Y., Hondo, H., and Nakano, S. 2017. Renewable energy and employment potential: A comparative analysis based on an input-output model, Journal of the Japan Institute of Energy, 96(1), 16-27. https://doi.org/10.3775/jie.96.16

National Development and Reform Committee of China, 2015. Enhanced actions on climate change: China's intended nationally determined contributions. (in Chinese), https://www4.unfccc.int/sites/ndcstaging/PublishedDocuments/China\%20First/ China's\%20First \%20NDC\%20Submission.pdf/ [accessed 31 January 2021].

Shirley, R., and Kammen, D. 2012. Estimating the potential impact of renewable energy, Renewable and Appropriate Energy Laboratory (RAEL), https://rael. berkeley.edu/wp-content/uploads/2016/03/RAEL-Green-Jobs-Report_-Shirleyand-Kammen_May2012.pdf [accessed 31 January 2021].

Timmer, M. P., Dietzenbacher, E., Los, B., Stehrer, R., and de Vries, G. J. 2015. An illustrated user guide to the World Input-Output Database: The case of global automotive production, Review of International Economics, 23, 575-605. https:// onlinelibrary.wiley.com/doi/abs/10.1111/roie.12178

Wang, J. 2016. Economic and environmental effects of power generation by renewable energies in China: an application of scenario input output analysis, Input-Output Analysis-Innovation and I-O Technique (Pan-Pacific Association for Input-Output Studies), 24(1), 35-48. (in Japanese)

Wei, M., Shana, P., and Daniel, K. 2010. Putting renewables and energy efficiency to work: How many jobs can the clean energy industry generate in the US, Energy Policy, 38, 919-931. https://doi.org/10.1016/j.enpol.2009.10.044 
Yoshioka, K., and Suga, M. 1997. Application of input output approach in environmental analysis: A study of scenario Leontief inverse, in Ueta, K. et al. An Econometric Approach to Environmental Problems, The Economic Analysis, 154, 87-132, Economic Research Institute, Economic Planning Agency. (in Japanese)

\section{Data sources}

China Electricity Council (CEC) (2021), List of basic data of electricity statistics in 2019, https://cec.org.cn/detail/index.html?3-292822. (in Chinese) [accessed 31 January 2021].

Institute for Economic Analysis of Next-generation Science and Technology (2016), Input-output table for analysis of next-generation energy system for 2005, http:// www.f.waseda.jp/washizu/table.html (in Japanese) [accessed 31 January 2021].

National Bureau of Statistics of China (NBSC) (2013), China energy statistical yearbook 2013, China Statistics Press. (in Chinese)

National Bureau of Statistics of China (NBSC) (2014), China economic census yearbook 2013, China Statistics Press (in Chinese)

National Bureau of Statistics of China (NBSC) (2015), 2012 Input output table of China, China Statistics Press. (in Chinese)

National Bureau of Statistics of China (NBSC) (2020), China statistical yearbook 2019, http://www.stats.gov.cn/tjsj/ndsj/2019/indexch.htm (in Chinese) [accessed 31 January 2021].

World Input-Output Database (2013), Environmental accounts-CHN_CO2, http:// www.wiod.org/database/eas13. [accessed 31 January 2021]. 